\title{
Hydrodynamic studies on liquid-liquid two phase flow separation in microchannel by computational fluid dynamic modelling
}

\author{
Chue Cui Ting ${ }^{1}$, Afiq Mohd Laziz ${ }^{1}$, Khoa Dang Dang Bui ${ }^{2,3}$, Ngoc Thi Nhu Nguyen ${ }^{2,3}$, Khoa Ta Dang ${ }^{2,3}$, \\ Pha Ngoc Bui ${ }^{2,3}$, An Si Xuan Nguyen ${ }^{2,3}$, Ngon Trung Hoang ${ }^{2,3}$, Ku Zilati Ku Shaari ${ }^{1}$, \\ Loi Hoang Huy Phuoc Pham 2,3,*
}

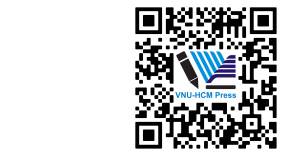

Use your smartphone to scan this QR code and download this article

${ }^{1}$ Chemical Engineering Department, Universiti Teknologi PETRONAS (UTP), 3260 Seri Iskandar, Perak, Malaysia

${ }^{2}$ Faculty of Chemical Engineering, Ho Chi Minh City University of Technology (HCMUT), 268 Ly Thuong Kiet Street, District 10, Ho Chi Minh City, Vietnam

${ }^{3}$ Vietnam National University Ho Chi Minh City, Linh Trung Ward, Thu Duc District, Ho Chi Minh City, Vietnam

\section{Correspondence}

Loi Hoang Huy Phuoc Pham, Faculty of Chemical Engineering, Ho Chi Minh City University of Technology (HCMUT), 268 Ly Thuong Kiet Street, District 10, Ho Chi Minh City, Vietnam

Vietnam National University Ho Chi Minh City, Linh Trung Ward, Thu Duc District, Ho Chi Minh City, Vietnam

Email: phhloi@hcmut.edu.vn

\section{History}

- Received: 27-02-2021

- Accepted: 26-4-2021

- Published: 09-5-2021

DOI : 10.32508/stdjet.v4i2.810

\section{Check for updates}

\begin{abstract}
Microfluidic systems undergo rapid expansion of its application in different industries over the few decades as its surface tension-dominated property provides better mixing and improves mass transfer between two immiscible liquids. Synthesis of biodiesel via transesterification of vegetable oil and methanol in microfluidic systems by droplet flow requires separation of the products after the reaction occurred. The separation technique for multiphase fluid flow in the microfluidic system is different from the macro-system, as the gravitational force is overtaken by surface force. To understand these phenomena completely, a study on the hydrodynamic characteristics of two-phase oil-methanol system in microchannel was carried out. A multiphase Volume of Fluid model was developed to predict the fluid flow in the microchannel. An inline separator design was proposed along with its variable to obtain effective separation for the oil-methanol system. The separation performance was evaluated based on the amount of oil recovered and its purity. The capability of the developed model has been validated through a comparison of simulation results with published experiment. It was predicted that the purity of recovered oil was increased by more than $46 \%$ when the design with side openings arranged at both sides of the microchannel. The highest percentage recovery of oil from the mixture was simulated at $91.3 \%$ by adding the number of side openings to ensure the maximum recovery. The oil that was separated by the inline separator was predicted to be at $100 \%$ purity, which indicates that no methanol contamination throughout the separation process. The purity of the separated product can be increased by manipulating the pressure drop across the side openings. Hence, it can be concluded that the separation in a large diameter microchannel system is possible and methodology can be tuned to achieve the separation goal. Finally, the simulation results showed that the present volume of fluid model had a good agreement with the published experiment.
\end{abstract}

Key words: microchannel, immiscible liquids separation, computational fluid dynamic, volume of fluid model, multiphase

\section{INTRODUCTION}

Liquid-liquid two phase separation is an important aspect when it comes to the usage of microchannel in performing certain chemical reactions that involve two immiscible liquids ${ }^{1}$. One of the applications of the usage of microreactor technology in chemical processes in the transesterification of vegetable oil and methanol is to produce biodiesel ${ }^{2}$. Heat and mass transfer are improved significantly via microfluidic device as it provides high surface to volume ratio ${ }^{3-6}$. As the reaction and fluid flow happen in the capillarysize channel, the mechanism of the fluid flow deviates from the macro-system as the effect of gravity and inertial force is not significant in the micro-system ${ }^{7}$. The capillary effect and viscous force overcome the gravity and inertial force, causing the fluid to behave differently. In order to design a separation system that can perform quick separation in the microchannel field, it is important to study the hydrodynamic characteristic of the fluid flow in the microchannel.

In macroscale, separation is done by exploiting the gravitational effect and the difference in density of the multiphase. However, in microscale, the effect of gravitational force is overtaken by the surface force, and the density difference of the two phases are small ${ }^{7}$. In another study, it was found that the microfluidics have apparatus length scale below the Laplace length scale $(\sqrt{\gamma /(\rho g)})$, which later proved that the effect of gravitational forces is negligible in microchannel ${ }^{8}$. By exploiting the surface forces in microfluidics, two phase separation is possible to perform in a single step.

Capillary pressure, $P_{\text {cap }}$ is a critical parameter in the microscale separation process to induce and maintain

Cite this article : Ting C C, Laziz A M, Bui K D D, Nguyen N T N, Dang K T, Bui P N, Nguyen A S X, Hoang N T, Shaari K Z K, Pham L H H P. Hydrodynamic studies on liquid-liquid two phase flow separation in microchannel by computational fluid dynamic modelling. Sci. Tech. Dev. J. - Engineering and Technology; 4(2):920-931. 
Copyright

(C) VNU-HCM Press. This is an openaccess article distributed under the terms of the Creative Commons Attribution 4.0 International license.

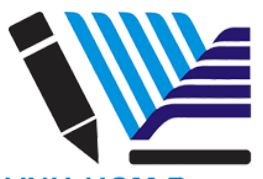

VNU-HCM Press separation $^{7,9,10}$. The $P_{\text {cap }}$ is given as ${ }^{7}$ :

$$
P_{c a p}=\frac{2 \gamma \cos \cos \theta}{r}
$$

where

$\gamma$ is the interfacial tension,

$\theta$ is the contact angle between the liquid phase and the solid wall of the microdevice

$r$ is the radius of curvature of the interface.

To achive a perfect separation, the capillary pressure must be higher than the outlet pressure drop ${ }^{11}$. Adamo et al. ${ }^{11}$ had proposed the outlet pressure drop as follow:

$$
\triangle P_{\text {outlet }}=\frac{12 \mu l Q}{\left(1-0.63 \frac{h}{w}\right) w h^{3}}
$$

where

$l, h$ and $w$ is the length, height and width of the channel respectively

$Q$ is the volumetric flow rate and $\mu$ is the dynamic viscosity of the liquid.

There are two main possible failures in the attempt to achieve two phase separation in the microchannel ${ }^{11}$. First is the retain of continuous phase in dispersed phase outlet and second is the breakthrough of dispersed phase which some of the dispersed phase flow together with the continuous phase through the continuous phase outlet. First scenario occurs when the capillary pressure of the continuous phase is insufficient to provide the driven force for all the continuous phases to flow to the continuous phase outlet. The capillary pressure of continuous phase is smaller than continuous outlet pressure in this scenario. Second failure happens when the capillary pressure of the dispersed phase is greater than the continuous pressure outlet, causing the dispersed phase to overcome the pressure to flow through the continuous outlet. Hence it is important to maintain the suitable pressure drop in the microchannel to induce the perfect separation. To achieve a perfect separation ${ }^{10}$, the outlet pressure drop must be in the range of:

$$
\triangle P_{c}^{\text {dispersed }}>\triangle P_{\text {outlet }}>\triangle P_{c}^{\text {continuous }}
$$

The outlet pressure drop can be tuned by modifying the capillary diameter as well as the capillary length as both are the function of the pressure drop outlet ${ }^{10}$. By tuning the pressure drop across the outlet to the desired range, perfect separation can be achieved. Currently, there are successful inline separators for the microfluidics that are proven to carry out fast and effective separation of the two immiscible liquids flow. However, the design of the separator requires a very fine capillaries array (less than $50 \mu \mathrm{m}$ ), which can cause difficulty for production of the very fine capillaries microchannel. The aim of this project is to conduct a numerical study on the hydrodynamics characteristic of liquid-liquid two phase flow separation in microchannel. In this present work, the separation is performed in the microchannel system with large capillary size (particularly more than $250 \mu \mathrm{m}$ ). Separation system with large capillary size has lesser pressure drop, and therefore is more difficult to carry out separation.

\section{RELATED WORK}

The separation of chloroform and water system at flow rate up to $0.4 \mathrm{ml} / \mathrm{min}$ has been performed by Castell et al. ${ }^{7}$. In this study, the segmented flow regimes of the two liquids are generated and separated into their component phases through an array of separation ducts. The outlet pressure drops at various positions were applied to achieve separation. The separation efficiency was quantified over a range of applied pressure differentials and inlet flow rates. It was demonstrated that the capillary pressure is sufficient to separate the two-phase flow through a narrow channel over a range of flow rates by applying appropriate pressure drop of the separator. Besides, it was also proved that the difference in capillary forces of the two different wetting property fluids allows the separation to be achieved by ensuring the passage of one phase through the separation ducts.

A comparison study showed that the separation technique performed by Kashid and Agar ${ }^{12}$ is similar to the separation technique used by Castell et al. ${ }^{7}$. The system used by Kashid and Agar ${ }^{12}$ was toluene and water on chips. The number of the narrow channels used is 100 . Kashid and Agar ${ }^{12}$ found that the separation can be achieved by applying the appropriate pressure drops at the two different outlets.

The liquid-liquid separation in microchannel was modelled using a Y-shaped flow splitter by Kashid et $a l .{ }^{13}$. In this study, two different materials were integrated on each of the branches of the Y-splitter, which are hydrophobic Teflon and hydrophilic steel to separate the organic and aqueous phase liquids. The findings found that the separation efficiency is independent with droplet velocity. However, an unequal flow ratio between the two liquids will affect the separation efficiency. The liquid with higher flow rate will contaminate the outlet, causing incomplete separation. This phenomenon is caused by the dominant of inertial force over wetting force. Besides, capillary size has no significant effect on the separation efficiency. This 
modelling work had performed a near-perfect separation in which the aqueous outlet still contains 5 percent of organic solution.

Another methodology which is similar to the research work by Kashid et al. ${ }^{13}$ is the separation of immiscible liquids within hydrophobic microchannel by inserting a metallic hydrophilic sidestream ${ }^{14}$. Two these studies have investigated the effect of the sidestream angle, sidestream penetration, sidestream internal diameter and the fluid properties. Besides, the mainstream outlet length have been manipulated as the outlet pressure drop is a function of length. From there, it was proved that separation of two-phase flow can be achieved by simply piercing the microchannel using a hydrophilic metal sidestream needle.

In one study, the liquid-liquid separation has been performed by applying porous capillaries to the inline separation of the microchannel ${ }^{10}$. It was found that suitable back pressure at the separator and the twophase separation can be achieved over a wide range of flow rates (100-1000 $\mu \mathrm{L} / \mathrm{min})$ by tuning the back pressure. Moreover, this study also reported that the pressure difference is the key to successful separation. To achieve a perfect separation, the outlet pressure drop has to be smaller than capillary pressure of solvent and greater than capillary pressure of the carrier. By adjusting the separator capillary diameter and length, the outlet pressure drop can be tuned to achieve a perfect separation.

In another study, the separation of liquid-liquid phase had been demonstrated by using membrane-based separator with integrated pressure control ${ }^{11}$. A membrane is used to separate organic and aqueous phase and a pressure differential is applied across the outlet. By applying a suitable back pressure on the organic outlet, it is able to provide sufficient pressure to prevent all the aqueous phase from permeating through the membrane.

\section{THE METHODOLOGY TO DEVELOP THE MODEL}

A Volume of Fluid (VOF) model was developed to model and investigate the flow behaviour in $\mathrm{mi}-$ crochannel. ANSYS Fluent was used for the simulation purpose in this study ${ }^{15}$. Some assumptions were made in this work to study the flow separation of immiscible liquids in microchannel:

1. The liquids are Newtonian liquids and are incompressible with constant surface tension and viscosity.

2. The flow in the microchannel is laminar.
3. The boundary condition along the solid surface is non-slip with no penetration.

4. No mass transfer and chemical reaction occur across the two liquids interface.

\section{Governing Equations}

The computational domain used in this work is twodimensional. The interface tracking between the phases in VOF method is done by solving the continuity equation for the volume fraction of one phase:

$$
\begin{aligned}
& \frac{1}{\rho_{p}}\left[\frac{\partial}{\partial t}\left(\alpha_{p} \rho_{p}\right)+\nabla \cdot \alpha_{p} \rho_{p} \vec{v}_{p}\right] \\
& =S+\sum_{q=1}^{n}\left(\dot{m}_{q p}-\dot{m}_{p q}\right)
\end{aligned}
$$

The momentum equation in VOF model is

$$
\begin{aligned}
& \frac{\partial}{\partial t}(\rho \vec{v})+\nabla \cdot(\rho \vec{v} \vec{v}) \\
& =-\nabla p+\nabla \cdot\left(\mu\left(\nabla \vec{v}+\nabla \vec{v}^{T}\right)\right)+\rho \vec{g}+\vec{F}
\end{aligned}
$$

The surface tension model in ANSYS Fluent is the continuum surface force (CSF) model proposed by Brackbill et al. ${ }^{16}$. The addition of the surface tension to the VOF model results in the source term in the momentum equation. The outlet pressure drop highly depends on the surface tension coefficient, $\sigma$, and the surface curvature as measured by two radii in orthogonal directions, $R_{1}$ and $R_{2}$ :

$$
p_{2}-p_{1}=\sigma\left(\frac{1}{R_{1}}+\frac{1}{R_{2}}\right)
$$

Wall adhesion angle is included to adjust the surface normal in the cells near the wall. It helps to adjust the curvature of the surface near the wall. Assuming $\theta_{w}$ is the contact angle at the wall, then the surface normal at the cell next to the wall is

$$
\widehat{n}=\widehat{n}_{w} \cos \cos \theta_{w}+\widehat{t}_{w} \sin \sin \theta_{w}
$$

\section{Boundary and Solver Setup}

A two-dimensional domain (Figure 1) was generated by using the ANSYS Geometry Modeler ${ }^{15}$. A mesh was generated, and inflation method was used on the wall boundary as the simulation requires high accuracy at the wall film. Mesh independent study was carried out to identify the suitable mesh size for this simulation work. The boundary setup was tabulated in Table 1. 


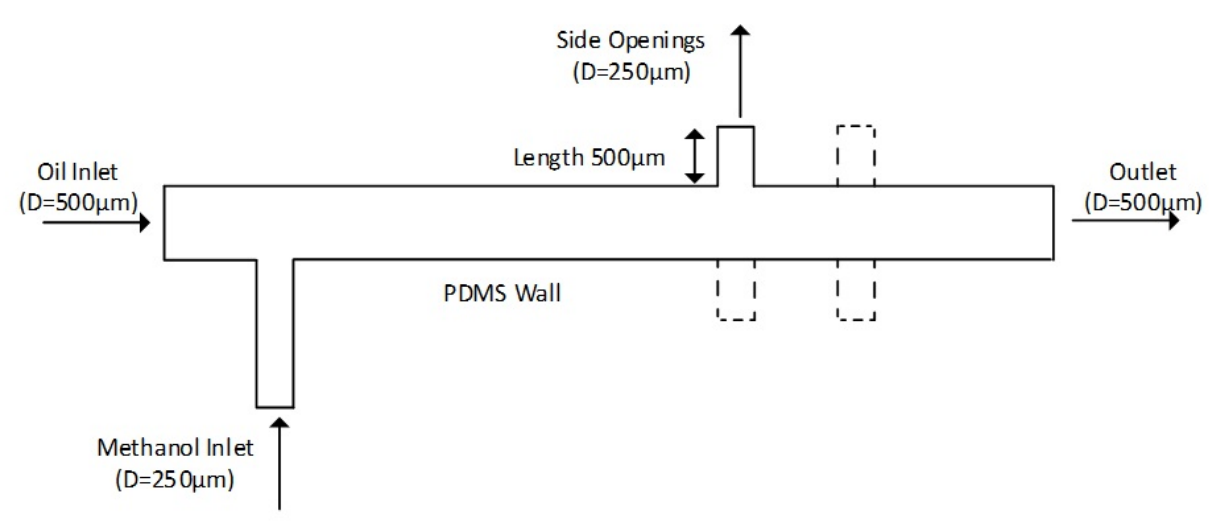

Figure 1: Schematic diagram of microchannel separator.

Table 1: Boundary and Solver Setup

\begin{tabular}{ll}
\hline Property/ Parameter & Fluid/ Value \\
Density $\left(\mathrm{kg} / \mathrm{m}^{3}\right)$ & Oil $=909.15$ \\
& Methanol $=785$ \\
Viscosity (Pa.s) & Oil $=0.069$ \\
& Methanol $=0.0005495$ \\
Interfacial Tension $(\mathrm{N} / \mathrm{m})$ & 0.00327 \\
Velocity $(\mathrm{m} / \mathrm{s})$ & Oil $=0.00138$ \\
& Methanol $=0.00214$ \\
Wall Adhesion & Oil/ Methanol $=180^{\circ}$ \\
\hline
\end{tabular}

\section{RESULTS AND DISCUSSION}

Two immiscible liquids, oil and methanol were introduced into the microchannel system by a T-junction and droplet flow were generated with oil as a primary phase enclosed the secondary phase, methanol as droplet. The mixture flows along the microchannel and eventually reaches the inline separator. The side openings provide exits for the oil to be separated from the mixture.

\section{Preliminary Design Selection}

Two types of designs were proposed to carry out the separation of the oil-methanol system. Design 1 (Figure 2) has the configuration of side openings located at both sides of the microchannel while design 2 (Figure 3 ) has the configuration of side openings located at one side of the microchannel. Figures 2 and 3 show the simulated oil volume fraction contour for separation in the oil-methanol system. Both the designs have 2 side openings with different configurations. The simulated result proved design 1 has better separation performance than design 2 in terms of total amount of oil removed and the purity of oil removed. Design 2 has a large amount of methanol escaped through the side openings, lowers the oil purity to $53.9 \%$. Design 1 was able to separate the oil from the mixture, retrieving almost $80 \%$ of pure oil from the mixture, while design 2 had recovered $67 \%$ of oil from the system. Based on this observation, design 1 is selected for the next analysis.

\section{Effect of Number of Side Openings}

Number of side openings is important as it determines the separation performance of an inline separator. The higher the number of side openings provides more exits for the primary phase to be separated from the system. The amount of oil allowed to separate from the system rises when the number of side openings increases. Table 2 shows the separation performance for the 3 types of separator with different numbers of side openings pair.

As shown in Table 2, when the number of side openings increases from 1 to 2 pairs, the percentage of oil recovery increases from $67.9 \%$ to $91.3 \%$. Further increase in the number of side openings will not 


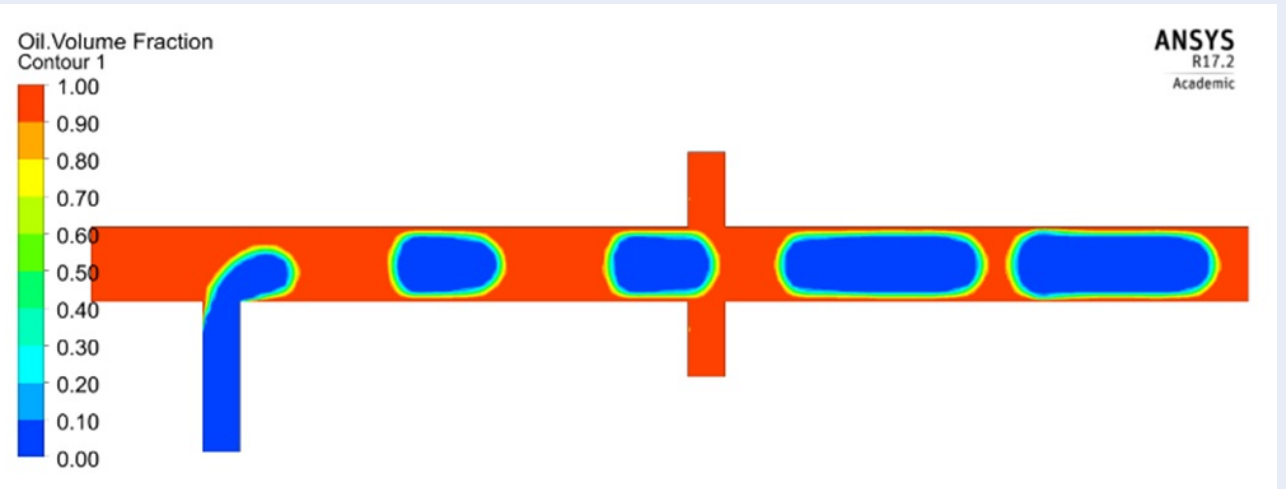

Figure 2: Oil volume fraction contour of inline separator design 1

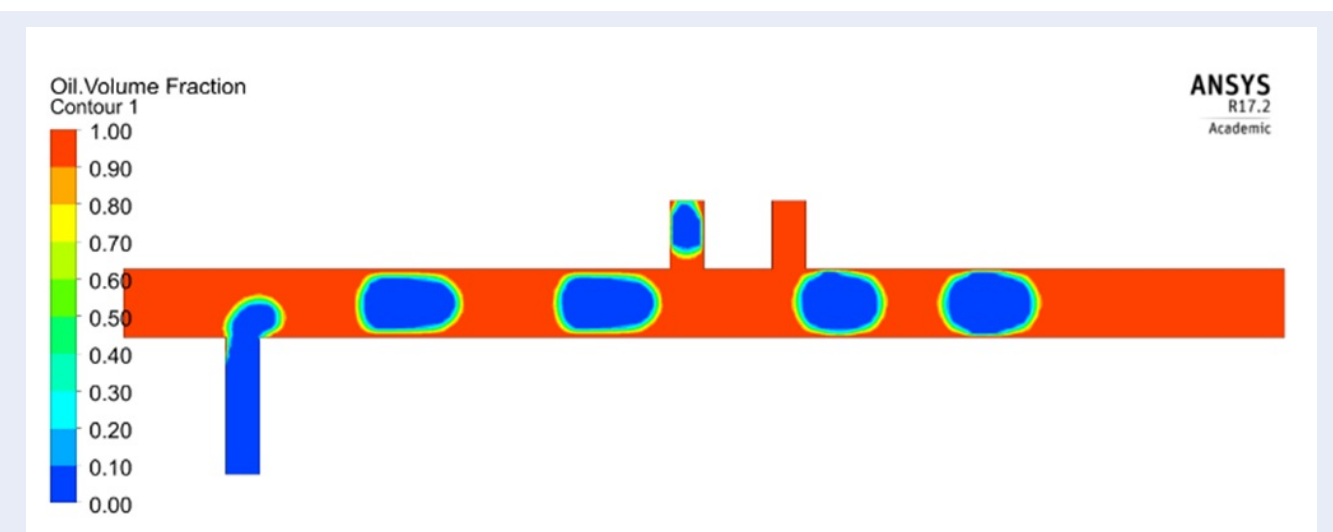

Figure 3: Oil volume fraction contour of inline separator design 2

Table 2: Effect of number of side openings on separation performance

\begin{tabular}{llll}
\hline $\begin{array}{l}\text { Number of Side Opening } \\
\text { Pair }\end{array}$ & $\begin{array}{l}\text { Percentage of oil recov- } \\
\text { ery (\%) }\end{array}$ & $\begin{array}{l}\text { Contamination of methanol at side } \\
\text { openings }\end{array}$ & $\begin{array}{l}\text { Purity of oil recovered } \\
(\%)\end{array}$ \\
1 & 67.9 & Yes & 99.3 \\
2 & 91.3 & Yes & 90.1 \\
3 & 91.3 & No & 100 \\
\hline
\end{tabular}

raise the amount of oil recovered as it is the maximum oil recovery that the inline separator can be achieved. The remaining $8.7 \%$ of the oil retains in the system and moves together with methanol as oil is the medium that wets the wall. A thin film of oil is found in between the wall and methanol droplet as a result of its wetting properties.

In terms of the oil recovered purity, separators with 2 pairs of side openings (Figure 4) provide worse separation than the 3 pairs side openings (Figure 5). The purity of oil increases from $90 \%$ to $100 \%$ by increasing the number of side openings pair from 2 to 3 . This phenomenon happens as the number of side openings pair increases the pressure drop of the system, retaining the methanol from escaping through the side openings, and hence, resulting in higher purity of the oil recovered. Based on the results, it is observed that 3 pairs of side openings are sufficient to carry out an effective separation given the process parameter.

The previous design with a low percentage of oil purity (inline separator with 2 pairs of side openings) was chosen for the next step of analysis. The objective of this is to enhance and improvise the separation based on the selected design. Two methods were proposed 


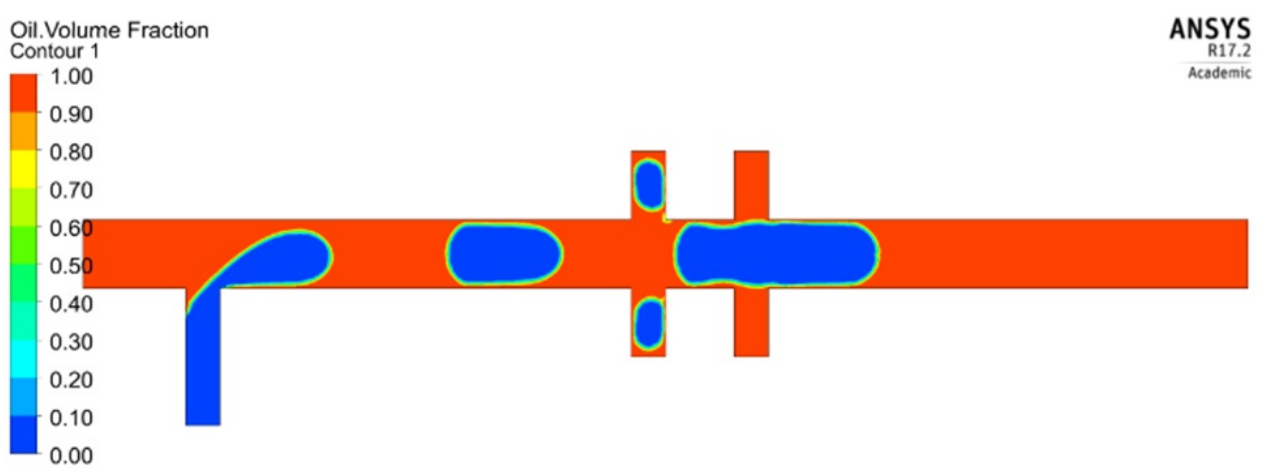

Figure 4: Oil volume fraction contour of inline separator with 2 pairs of side openings

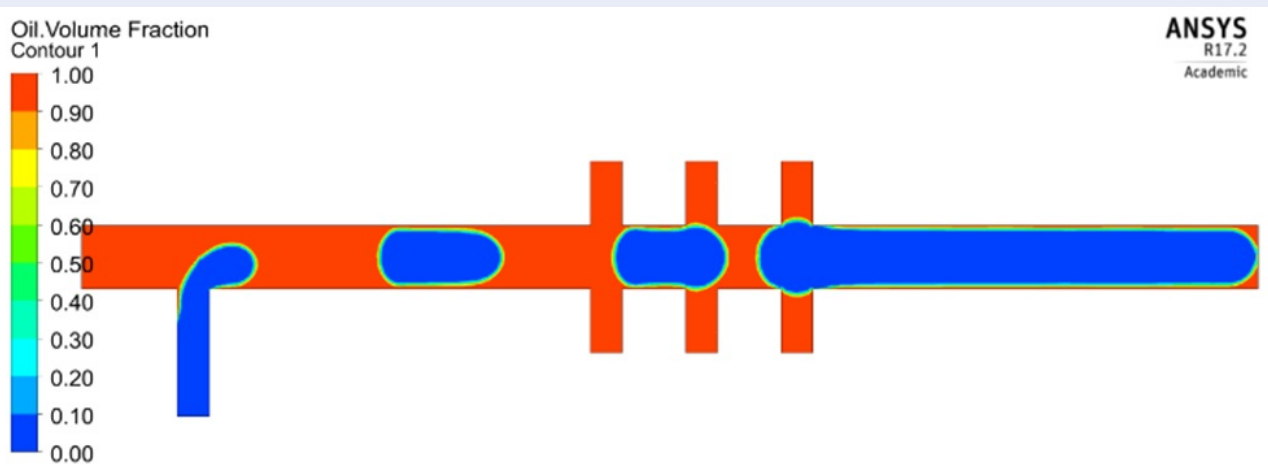

Figure 5: Oil volume fraction contour of inline separator with 3 pairs of side openings

to improve the design with fixed number of side openings. The methods are:

1. Increase the side opening's length.

2. Applied an external resistance on the side openings.

\section{Effect of Side Opening's Length}

Table 3 shows the separation performance of inline separator. The simulation result (Figure 6) shows the improvement of the recovered oil purity as the length of the side openings is increased. The pressure drop across the outlet is given by (2) and it shows the proportionality of the pressure drop and the length of the channel. By increasing the length of the outlet channel, the pressure drop across the side openings increases. For methanol to pass through the side openings, it must have sufficient capillary pressure to overcome the pressure drop across the side openings. Therefore, by increasing the length of the side openings, it prevents the methanol from flowing into side openings as the methanol droplet has insufficient capillary pressure to overcome the pressure drop across the side openings. From Table 3, it can be seen that $750 \mu \mathrm{m}$ side openings increase the purity of the recovered oil to $100 \%$. Further increases inside openings length will maintain the purity of oil recovered at its maximum and this can be observed at $1000 \mu \mathrm{m}$ side openings with $100 \%$ recovered oil purity.

Increasing the length of side openings will reduce the percentage of oil recovered, as part of the oil fraction has insufficient capillary pressure to overcome the increase in the side opening pressure drop. This can be shown as the side opening length increases from $500 \mu \mathrm{m}$ to $750 \mu \mathrm{m}$ and $1000 \mu \mathrm{m}$, the percentage of oil recovered reduces from 91.3 to 82.9 and $82 \%$ respectively.

\section{Effect of External Resistance in the Side Openings}

The purity of recovered oil can be enhanced by applying a resistance in the side openings outlet. By do- 


\begin{tabular}{|c|c|c|c|}
\hline $\begin{array}{l}\text { Length of side openings } \\
(\mu \mathrm{m})\end{array}$ & $\begin{array}{l}\text { Percentage of oil recovery } \\
\text { (\%) }\end{array}$ & $\begin{array}{l}\text { Contamination of } \\
\text { methanol at side openings }\end{array}$ & Purity of oil recovered (\%) \\
\hline 500 & 91.3 & Yes & 90.1 \\
\hline 750 & 82.9 & No & 100 \\
\hline 1000 & 82.0 & No & 100 \\
\hline
\end{tabular}

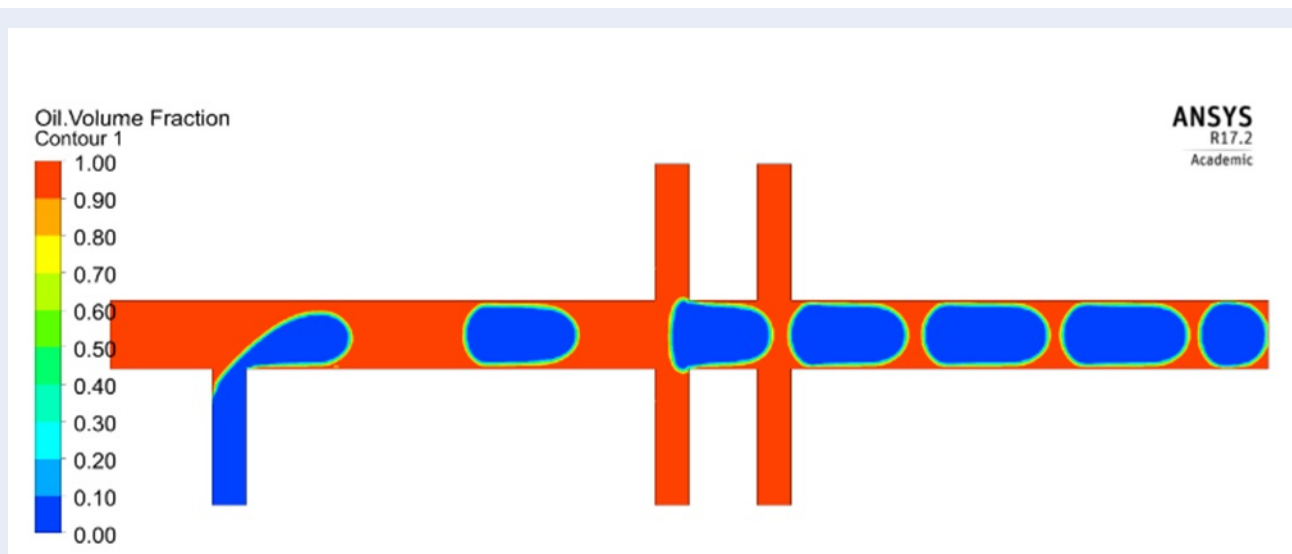

Figure 6: Oil volume fraction contour of inline separator with $1000 \mu \mathrm{m}$ long of side openings

ing this step, the pressure drop across the side openings increases, adding the difficulty for the methanol to pass through the side openings. The external resistance is represented by the reduction in the width of the side openings in the simulation. The first pair of the side openings width is reduced from $250 \mu \mathrm{m}$ to $150 \mu \mathrm{m}$. The comparison of the two separators is shown in Table 4.

From the simulation results (Fig. 7), it proves that by applying external resistance (reduction in the side openings' width) on the side openings, the purity of the recovered oil increases from $90 \%$ to $100 \%$. Pure product can be obtained through this methodology and the problem of methanol flowing into the side openings can be overcome. When external resistance (usually a thin rod) is applied, and inserted into the side openings, the cross-sectional area of the side openings decreases. According to (8), the pressure drop of across the outlet channel is inversely proportional to the width and height of the channel. The pressure drop of the side openings with applied resistance is larger than the one without. Since the crosssectional area of the side openings decreases, the pressure drop across the side openings increases. The methanol will need to have higher capillary pressure to overcome the large pressure drop. As a result of this, the flow of methanol into the side openings can be prevented.

However, the effect of the external resistance on the percentage of oil recovery is similar with cases of increased inside openings length. As the pressure drop across the side openings increases, portion of the oil will have insufficient capillary pressure to overcome the increment in pressure drop. Hence some of the oil will not be able to flow into the side opening, resulting in the reduction of the oil recovery percentage.

\section{Relationship between the Pressure Drop and Separation Performance}

The pressure drop across the side openings are obtained based on the simulated results of 2 pairs of side openings inline separator. A graph of separation performance versus the pressure drop of side openings is plotted (Fig. 8).

Based on the graph plotted it is clearly seen that the purity of the separation product is proportional to the pressure drop of the outlet. As the pressure drop of the side openings increases, the difficulty of the methanol to enter side opening increases. Hence the methanol will be separated from the oil phase. The other curve shows the relationship between the percentage of oil recovery and the pressure drop of side openings. As the pressure drop of the side openings increases, the lesser the oil being separated as some of the oil has 


\begin{tabular}{llll} 
Table 4: Effect of External Resistance on Separation Performance & \\
\hline $\begin{array}{l}\text { Width of first pair of side open- } \\
\text { ings }(\mu \mathrm{m})\end{array}$ & $\begin{array}{l}\text { Percentage } \\
\text { covery }(\%)\end{array}$ & $\begin{array}{l}\text { Contamination } \\
\text { methanol at side openings }\end{array}$ & re- \\
250 & 91.3 & Yes & 90.1 \\
150 & 79.4 & No & 100 \\
\hline
\end{tabular}

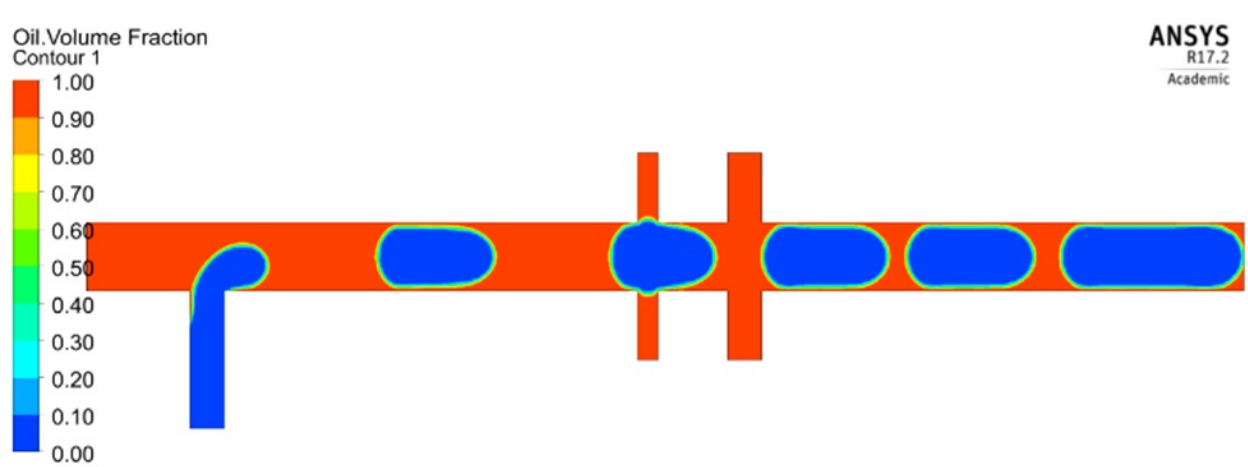

Figure 7: Oil volume fraction contour of inline separator with resistance
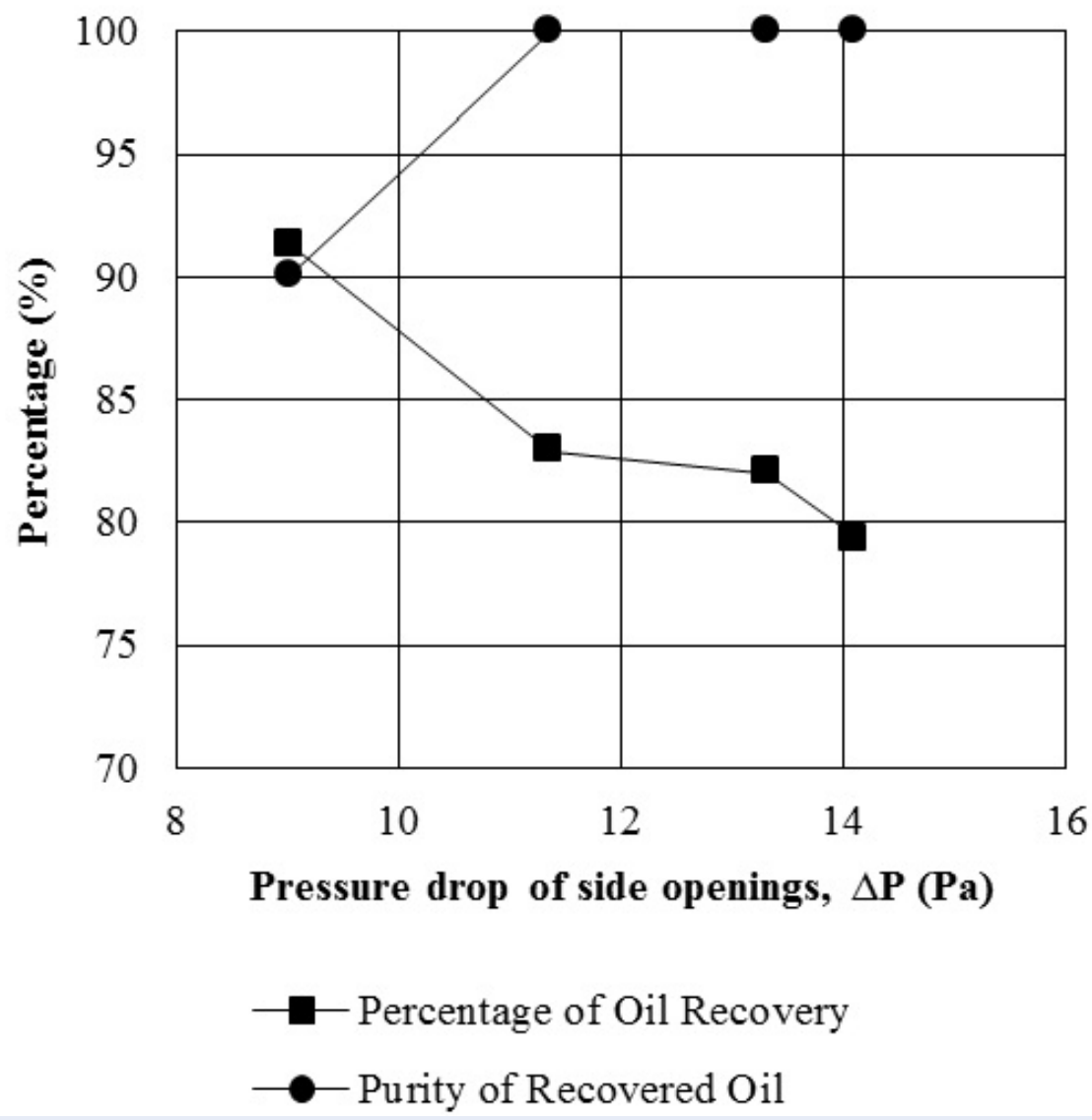

Figure 8: Graph of separation performance vs pressure drop 
not sufficient pressure to enter the side openings. Less oil is being recovered from the system as it retains in the main outlet and to be discharged together with methanol. The finding shows the significance of the pressure drop across the side openings in achieving microchannel inline separation.

\section{Model Validation Study}

In this study, the experimental result from Garstecki et al. ${ }^{17}$ is used to validate the accuracy of the above VOF model. The geometry of the microchannel used in Garstecki et al.'s experiment is a T-junction as shown in Fig. 9. The diameter of microchannel is 100 $\mathrm{mm}$ and the inlet has a width of $50 \mathrm{~mm}$. Oil is used as the continuous phase and water as dispersed phase. The main purpose of Garstecki et al.'s experiment ${ }^{17}$ is to produce different droplet sizes by injecting various volumetric flow rate ratio between oil and water into T-junction microchannel. Three different droplet sizes have been observed in range of the ratio between the droplet length, $\mathrm{L}_{d}$, to the channel width, $\mathrm{w}_{c}$. Table 5 shows the details of experimental conditions for all droplet size scenarios.

Fig. 10 shows the simulation results of the droplet predicted from the VOF model at different volumetric flow conditions (see Table 5). It can be found in the Fig. 10 that increasing the oil-to-water ratio leads to the increase of the droplet size. This finding is in corresponding with the study of Garstecki et al. ${ }^{17}$. The droplet lengths predicted from the VOF model and observed from the experiment ${ }^{17}$ are presented in Table 6. As can be seen from Table 6, the length deviations between the simulation and experimental results are around 5\%. This finding revealed that good agreement was observed between the simulation results and the published experimental data.

\section{CONCLUSION}

The flow behaviour of two immiscible liquids in microchannel is studied using the VOF model that is available in ANSYS Fluent software. Separation of two immiscible liquids in the microchannel by using a large diameter inline separator system is proposed at the earlier stage of the project. By conducting this study, this project proves that inline separation by large diameter separator is possible.

The project is done by using the squeezing regime at the inlet flow, with the velocity of oil phase at 0.00138 $\mathrm{m} / \mathrm{s}$ and velocity of methanol phase at $0.00214 \mathrm{~m} / \mathrm{s}$, which bring difficulties for the separation as the two fluids are flowing at a very slow velocity. The main interest of this project is to recover the oil from the mixture, as the oil phase is the main product of the transesterification. Therefore, the separation performance will be evaluated based on the recovered oil product. Preliminary study is conducted to identify the suitable design for the inline separator. It is proven that the design with side openings arranged at both sides of the microchannel gives better separation performance than the design with side openings arranged at one side of the microchannel. The purity of recovered oil is increased by more than $46 \%$. Based on this observation, the project is continued with selected design.

Further analysis is carried out on the selected geometry to investigate the effect of number of side openings, effect of side openings' length and effect of external resistance on the separation performance of the inline separator. It is observed that the highest percentage recovery of oil from the mixture that can be achieved is $91.3 \%$. This method can be achieved by adding the number of side openings to ensure the maximum recovery. The oil that is separated by the inline separator is found to be at $100 \%$ purity, which indicates that no methanol contamination throughout the separation process.

For the cases where the contamination of methanol occurred, whereby the methanol is escaping into the side openings together with the oil phase, this problem can be overcome by applying larger pressure drop across the side openings. This methodology can be achieved by increasing the length of the side openings, or by applying external resistance in the side openings. The purity of the recovered oil is proved to be increased up to $100 \%$, whereby all the methanol will flow through the main outlet.

The project has demonstrated that the separation of oil-methanol system in microchannel can be achieved using a higher number of side openings, which is 3 pairs of side openings for the selected oil and methanol flow rate. The purity of the separated product can be increased by manipulating the pressure drop across the side openings. Hence, it can be concluded that the separation in a large diameter microchannel system is possible and methodology can be tuned to achieve the separation goal.

Finally, the developed VOF model was validated against a recently published experimental data. The validation study shows that the present VOF model had a good agreement with the published experiment.

\section{ACKNOWLEDGEMENTS}

We acknowledge the support of time and facilities from Ho Chi Minh City University of Technology (HCMUT), VNU-HCM and Universiti Teknologi PETRONAS (UTP) for this study. 


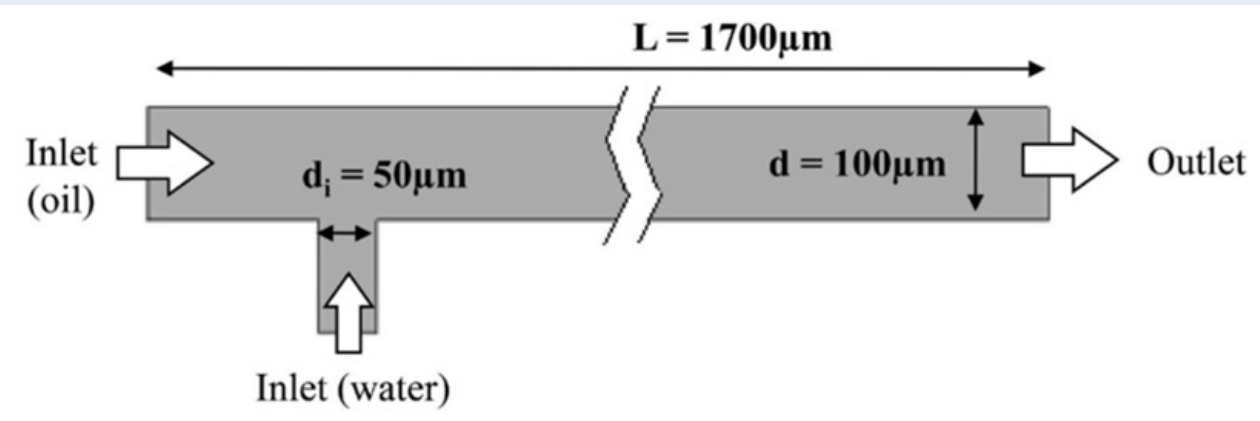

Figure 9: Computational domain of the microchannel is reproduced from Garstecki et al. ${ }^{17}$ for the model validation

Table 5: Experimental conditions ${ }^{17}$ used for the model validation

\begin{tabular}{lllll}
\hline Droplet name & Droplet size range & \multicolumn{2}{l}{ Inlet volume flow rate $(\mu \mathrm{L} / \mathrm{s})$} & Water-oil flow rate ratio, $\mathrm{Q}_{o} / \mathrm{Q}_{w}$ \\
& & $\mathrm{Q}_{\text {oil }}$ & $\mathrm{Q}_{\text {water }}$ & \\
Short & $\mathrm{Ld} \leq 2 \mathrm{w}_{c}$ & 0.028 & 0.010 & 0.36 \\
Middle & $2 \mathrm{w}_{c}<\mathrm{L}_{d} \leq 6 \mathrm{w}_{c}$ & 0.028 & 0.025 & 0.89 \\
Long & $\mathrm{L}_{d}>6 \mathrm{w}_{c}$ & 0.28 & 0.111 & 0.396 \\
\hline
\end{tabular}

a)

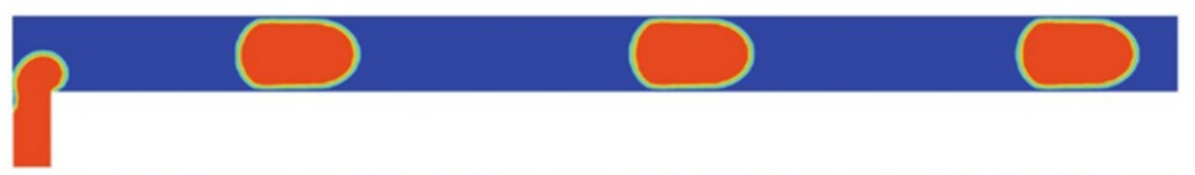

b)

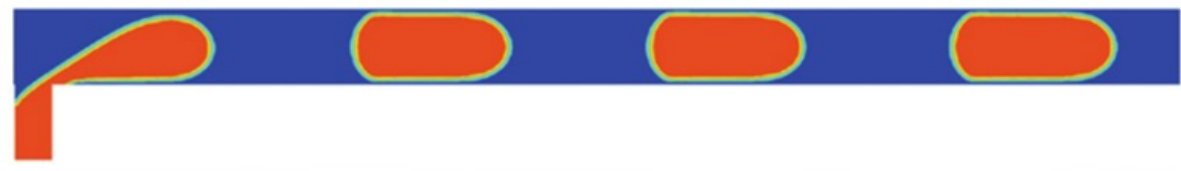

c)

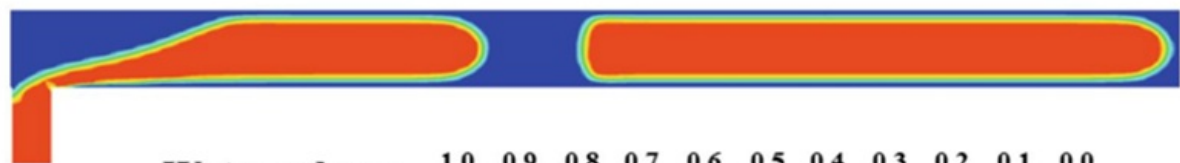

Water volume

$\begin{array}{lllllllllll}1.0 & 0.9 & 0.8 & 0.7 & 0.6 & 0.5 & 0.4 & 0.3 & 0.2 & 0.1 & 0.0\end{array}$

fraction

Figure 10: Predictions of droplet at different sizes: (a) short droplet, b) middle droplet and c) long drop

Table 6: Droplet length comparison between simulation and experiment

\begin{tabular}{llll}
\hline Droplet name & \multicolumn{3}{c}{ Droplet length $(\mathrm{mm})$} \\
& VOF model & Experiment $^{17}$ & Deviation (\%) \\
Short & 154 & 161 & 4.3 \\
Middle & 214 & 209 & 2.4 \\
Long & 1024 & 1058 & 3.2 \\
\hline
\end{tabular}




\section{LIST OF ABBREVIATION}

CSF Continuum surface force

PTFE Polytetrafluoroethylene

VOF Volume of Fluid

\section{COMPETING INTERESTS}

The authors declare that they have no conflicts of interests.

\section{AUTHORS' CONTRIBUTIONS}

The research methodology was conceptually proposed by Chue Cui Ting and Afiq Mohd Laziz. Original draft was prepared by Chue Cui Ting. The research was supervised by Khoa Dang Dang Bui, Ngoc Thi Nhu Nguyen, Khoa Ta Dang Pha, Ngoc Bui, An Si Xuan Nguyen, Ngon Trung Hoang, Ku Zilati Ku Shaari and Loi Hoang Huy Phuoc Pham. All authors have read and agreed to the published version of the manuscript.

\section{REFERENCES}

1. Okubo Y, et al. Microchannel devices for the coalescence of dispersed droplets produced for use in rapid extraction processes. Chemical Engineering Journal. 2004;101(1-3):39-48. Available from: https://doi.org/10.1016/j.cej.2003.10.025.

2. Canter N. Making biodiesel in a microreactor. Tribol. Lubr. Technol. 2006;62:15-17.

3. Ehrfeld W, Hessel V, Loewe H. Microreactors: New Technology for Modern Chemistry. Wiley-VCH, Weinheim. 2000;Available from: https://doi.org/10.1002/3527601953.

4. Kobayashi J, Mori Y, Kobayashi S. Multiphase organic synthesis in microchannel reactors. Chem. Asian J. 2006;1:22-35. PMID: 17441035. Available from: https://doi.org/10.1002/asia. 200600058.

5. Jovanovic J, Rebrov EV. Phase transfer catalysis in segmented flow in a microchannel: fluidic control of selectivity and productivity. Ind. Eng. Chem. Res. 2010;49:2681-2687. Available from: https://doi.org/10.1021/ie9017918.
6. Kashid MN, Renken A, Kiwi-Minsker L. CFD modelling of liquid-liquid multiphase microstructured reactor: Slug flow generation. Chemical Engineering Research and Design. 2010;88(3):362-368. Available from: https://doi.org/10.1016/j. cherd.2009.11.017.

7. Castell OK. Liquid-liquid phase separation: Characterisation of a novel device capable of separating particle carrying multiphase flows. Lab Chip. 2009;9:388-396. PMID: 19156287. Available from: https://doi.org/10.1039/B806946H.

8. Gunther A, Jensen KF. Multiphase microuidics: from ow characteristics to chemical and materials synthesis. Lab on a Chip. 2006;6:1487-1503. PMID: 17203152. Available from: https: //doi.org/10.1039/B609851G.

9. Kralj J, Sahoo H, Jensen K. Integrated continuous microfluidic liquid-liquid extraction. Lab Chip. 2007;7(2):256-263. PMID: 17268629. Available from: https://doi.org/10.1039/B610888A.

10. Phillips TW, et al. Microscale extraction and phase separation using a porous capillary. Lab Chip. 2015;15(14):29602967. PMID: 26054926. Available from: https://doi.org/10. 1039/C5LC00430F.

11. Adamo A, Heider PL, et al. Membrane-Based, LiquidLiquid Separator with Integrated Pressure Control. Industrial \& Engineering Chemistry Research. 2013;52(31):10802-10808. Available from: https://doi.org/10.1021/ie401180t.

12. Kashid MN, Agar DW. Hydrodynamics of liquid-liquid slug flow capillary microreactor: flow regimes, slug size and pressure drop. Chemical Engineering Journal. 2007;131(1):1-13. Available from: https://doi.org/10.1016/j.cej.2006.11.020.

13. Kashid MN, et al. Liquid-Liquid Slug Flow In A Capillary: An Alternative To Suspended Drop Or Film Contactors. Industrial \& Engineering Chemistry Research. 2007;46(25):8420-8430. Available from: https://doi.org/10.1021/ie070077x.

14. Scheiff F, et al. The separation of immiscible liquid slugs within plastic microchannels using a metallic hydrophilic sidestream. Lab on a Chip. 2011;11(6):1022-1029. PMID: 21279200. Available from: https://doi.org/10.1039/c0lc00442a.

15. Fluent. FLUENT 6.3 User's Guide. Fluent Inc. 2006;

16. Brackbill JU, et al. A Continuum Method for Modeling Surface Tension. J. Comput. Phys. 1992;100:335-354. Available from: https://doi.org/10.1016/0021-9991(92)90240-Y.

17. Garstecki P. Formation of droplets and bubbles in a microfluidic T-junction-scaling and mechanism of break-up. Lab Chip. 2006;6:437-446. PMID: 16511628. Available from: https: //doi.org/10.1039/b510841a. 


\title{
Nghiên cứu về thủy động lực học của sự phân tách dòng chảy giữa hai pha lỏng-lỏng trong vi kênh bằng mô hình tính toán động lực học chất lưu
}

\author{
Chue Cui Ting ${ }^{1}$, Afiq Mohd Laziz' ${ }^{1}$, Bùi Đặng Đăng Khoa ${ }^{2,3}$, Nguyễn Thị Như Ngọc $^{2,3}$, Tạ Đăng Khoa ${ }^{2,3}$, \\ Bùi Ngọc Pha ${ }^{2,3}$, Nguyễn Sĩ Xuân Ân ${ }^{2,3}$, Hoàng Trung Ngôn ${ }^{2,3}$, Ku Zilati Ku Shaari ${ }^{1}$, \\ Phạm Hoàng Huy Phước Lợi ${ }^{2,3}$,*
}

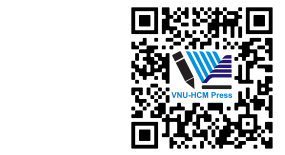

Use your smartphone to scan this QR code and download this article

${ }^{1}$ Khoa Kỹ thuât Hóa hoc, Trường Đai học Kỹ thuật Petronas, 3260 Seri Iskandar, Perak, Malaixia

${ }^{2}$ Khoa Kỹ thuật Hóa học, Truờng Đại học Bách Khoa TP. Hồ Chí Minh, 268 Lý Thường Kiệt, Quận 10, Thành phố Hồ Chí Minh, Việt Nam

${ }^{3}$ Đại học Quốc gia Thành phố Hồ Chi Minh, Phường Linh Trung, Quận Thủ Đức, Thành phố Hố Chi Minh, Việt Nam

Liên hệ

Phạm Hoàng Huy Phước Lợi, Khoa Kỹ thuật Hóa học, Trường Đại học Bách Khoa TP. Hô Chí Minh, 268 Lý Thường Kiệt, Quận 10, Thành phố Hồ Chí Minh, Việt Nam

Đại học Quốc gia Thành phố Hồ Chi Minh, Phường Linh Trung, Quận Thủ Đức, Thành phố Hồ Chi Minh, Việt Nam

Email: phhloi@hcmut.edu.vn

Lịch sử

- Ngày nhận: 27-02-2021

- Ngày chấp nhận: 26-4-2021

- Ngày đăng: 09-5-2021

DOI : 10.32508/stdjet.v4i2.810

Check for updates

\section{TÓM TÁT}

Trong những thập niên gần đây, hệ thống vi lưu được dùng nhiều trong các ngành công nghiệp khác nhau, vì nhờ đặc tính sức căng bề mặt của nó đã giúp cho sự hòa trộn tốt hơn và tăng sự truyền khối giữa hai chất lỏng không hòa tan. Quá trình tổng hợp diesel sinh học thông qua phản ứng tổng hợp este của dầu thực vật và methanol trong hệ thống vi lưu nhỏ giọt yêu cầu tách các sản phẩm sau khi phản ứng xảy ra. Kỹ thuật tách dòng chất lỏng nhiều pha trong hệ thống vi lưu khác với hệ vĩ mô, do lực hấp dẫn bị lực bề mặt chi phối. Để hiểu rõ hiện tượng này, nghiên cứu về đặc điểm thủy động lực học của hệ thống dâu-methanol trong vi kênh đã được thực hiện. Mô hình thể tích chất lỏng nhiều pha đã được phát triển để dự đoán dòng chất lỏng trong vi kênh. Một bộ tách nội tuyến đã được thiết kế cùng với biến số của nó để có được sự phân tách hiệu quả cho hệ thống dầu-methanol. Hiệu suất của quá trình phân tách đã được đánh giá dựa trên lượng dầu thu hồi và độ tinh khiết của nó. Độ chính xác của mô hình đã phát triển đã được xác nhận thông qua việc so sánh kết quả mô phỏng với số liệu thực nghiệm đã công bố. Độ tinh khiết của dầu thu hồi đã được dự đoán tăng hơn 46\% khi thiết kế với các lỗ ra được bố trí ở cả hai bên của vi kênh. Tỷ lệ phần trăm thu hồi cao nhất của dầu từ hỗn hợp được mô phỏng ở mức 91,3\% bằng cách tăng số lượng lỗ ra ở hai bên để đảm bảo thu hồi tối đa. Dầu được tách bằng thiết bị tách nội tuyến được dự đoán là có độ tinh khiết 100\%, điều này cho thấy rằng không có nhiễm methanol trong suốt quá trình tách. Độ tinh khiết của sản phẩm tách có thể được tăng lên bằng cách điều chỉnh độ giảm áp suất trên các lỗ ra. Do đó, có thể kết luận rằng việc phân tách trong một hệ thống vi kênh có đường kính lớn là có thể thực hiện được và phương pháp này có thể được điều chỉnh để đạt được mục tiêu phân tách. Cuối cùng, kết quả mô phỏng cho thấy mô hình thể tích chất lỏng này phù hợp với thí nghiệm đã công bố.

Từ khoá: vi kênh, tách chất lỏng không hòa tan nhau, tính toán động lực học chất lưu, mô hình thể tích chất lỏng, nhiều pha
Trích dẫn bài báo này: Ting C C, Laziz A M, Khoa B D D, Ngọc N T N, Khoa T D, Pha B N, Ân N S X, Ngôn H T, Shaari K Z K, Lợi P H H P. Nghiên cứu về thủy động lực học của sự phân tách dòng chảy giữa hai pha lỏng-lỏng trong vi kênh bằng mô hình tính toán động lực học chất lưu. Sci. Tech. Dev. J. - Eng. Tech.; 4(2): 920-931. 